\title{
Soil stabilisation by water repellency under no-till management for soils with contrasting mineralogy and carbon quality
}

\author{
Filipe Behrends Kraemer ${ }^{\mathrm{a}, \mathrm{b}, \mathrm{c}, *}$, Paul D. Hallett ${ }^{\mathrm{d}}$, Héctor Morrás ${ }^{\mathrm{b}}$, Lucas Garibaldi ${ }^{\mathrm{e}, \mathrm{c}}$, \\ Diego Cosentino ${ }^{\mathrm{f}, \mathrm{c}}$, Matías Duval ${ }^{\mathrm{g}}$, Juan Galantini ${ }^{\mathrm{g}, \mathrm{h}}$ \\ ${ }^{a}$ Cátedra de Manejo y Conservación de Suelos, Facultad de Agronomía, Universidad de Buenos Aires, Argentina \\ ${ }^{\mathrm{b}}$ Instituto de Suelos-CIRN-INTA, Argentina \\ c CONICET, Argentina \\ ${ }^{\mathrm{d}}$ School of Biological Sciences, St. Machar Drive, University of Aberdeen, AB24 3UU, United Kingdom \\ ${ }^{\mathrm{e}}$ Instituto de Investigaciones en Recursos Naturales, Agroecología y Desarrollo Rural (INRAD). Universidad Nacional de Rio Negro, CONICET, Argentina \\ ${ }^{\mathrm{f}}$ Cátedra de Edafología, Facultad de Agronomía, Universidad de Buenos Aires, CONICET, Argentina \\ ${ }^{g}$ CERZOS-Departamento de Agronomía, Universidad Nacional del Sur, Bahía Blanca, Argentina \\ ${ }^{\mathrm{h}}$ Comision de Investigaciones Científicas (CIC), Bs. As., Argentina
}

\section{A R T I C L E I N F O}

Handling Editor: Ingrid Kögel-Knabner Keywords:

Water drop penetration time

Repellency index

Soil quality

Mollisols

Vertisols

\begin{abstract}
A B S T R A C T
No-till soil management is common around the globe, but the impacts on soil structural quality varies depending on cropping practice and inherent soil properties. This study explored water repellency as a driver of soil stabilization, as affected by soil mineralogy, granulometry and organic carbon quality in three Mollisols and one Vertisol under no-till management and with different levels of cropping intensity. The studied soils were located along a west-east textural gradient in the northern part of the Pampean region of Argentina. Cropping intensity treatments evaluated in each one of the soils were: Poor Agricultural Practices (PAP) close to a monoculture, Good Agricultural Practices (GAP) involving a diverse crop rotation and more targeted inputs, and the soil in the surrounding natural environment (NE) as a reference. NE had the greatest aggregate stability (MWD) of all cropping intensities, with GAP being more stable than PAP for Mollisols and PAP being greater than GAP for the Vertisol. This trend matched the Repellency Index $\left(R_{\text {index }}\right)$, with greater $R_{\text {index }}$ associated with greater MWD, including the difference between the Mollisols and Vertisol. However, the persistence of water repellency, measured by the Water Drop Penetration Time (WDPT) test followed the trend NE > GAP > PAP regardless of soil type. The increases in $\mathrm{R}_{\text {index }}$ and MWD were related to higher intensification as measured by the Crop Sequence Index, and decreased with greater soybean occurrence in the sequence. Both WDPT and $\mathrm{R}_{\text {index }}$ were closely related to aggregate stability, particularly for Mollisols. These results highlight the importance of considering the inherent soil characteristics texture and mineralogy to understand aggregate stabilization mediated by water repellency. Good correlations between soil water repellency, organic carbon fractions and aggregate stability were found. Under no-till, crop rotations can be altered to increase soil stability by inducing greater water repellency in the soils. The findings suggest that water repellency is a major property influencing soil structure stabilization, thus providing a useful quality indicator.
\end{abstract}

\section{Introduction}

From the mid- to late-1990s no-till soil management expanded drastically worldwide, facilitated by the use of herbicides and improved no-till technologies (Derpsch et al., 2010). Its prominence has grown most in regions where continuous tillage degraded previously fertile soils, particularly in South America (Durán et al., 2011). In Argentina, no-till farming (NT) is now practiced on almost $90 \%$ of its cultivated land, 27 million hectares in total (AAPRESID, 2017). No-till has well documented benefits for erosion control, increasing shallow organic carbon, creating more stable soil aggregates, and decreasing production costs (Abid and Lal, 2009; Kirkegaard and Hunt, 2010; Derpsch et al., 2010). However, soil properties may also degrade under no-till, particularly if continuous cropping is also practiced (Alvarez et al., 2009;

\footnotetext{
* Corresponding author.

E-mail addresses: filipebk@agro.uba.ar (F. Behrends Kraemer), paul.hallett@abdn.ac.uk (P.D. Hallett), morras.hector@inta.gob.ar (H. Morrás), lgaribaldi@unrn.edu.ar (L. Garibaldi), cosenti@agro.uba.ar (D. Cosentino), jgalanti@criba.edu.ar (J. Galantini).
} 
Sasal et al., 2006). No-till together with monoculture, especially with a high frequency of soybean (Glycine Max ssp), can enhance soil compaction and penetration resistance (Mahboubi et al., 1993; Chagas et al., 1994). Platy structures are often found under NT in silty soils in the Pampean region of Argentina, affecting physical behaviour and soil quality (Morrás et al., 2004, 2012; Bonel et al., 2005; Sasal et al., 2009, 2016). Crop sequences with high soybean frequency can also result in poorer aggregate stability, less macroporosity, and diminishing organic carbon content compared to a more diverse crop sequence (Novelli et al., 2013; Sasal et al., 2009; Kraemer, 2015). Improvements by double-cropping, such as wheat/soybean and wheat/late corn are growing in prominence (Caviglia and Andrade, 2010). This intensification may result in positive effects on soil organic carbon (Studdert et al., 2010), aggregate stability (Novelli et al., 2011; Sasal, 2012) and on decreasing runoff (Sasal et al., 2010) among others.

Considerable research now explores how soil management and cropping practices can mitigate soil structural degradation. In Argentina, the BIOSPAS consortium (2009) (http://www.mincyt.gob. ar/_post/descargar.php?idAdjuntoArchivo $=22693$ ), has a long-term objective of identifying soil indicators of sustainable no-till cultivation (Wall, 2011), particularly those related with biological processes. These indicators should account for the impacts of different management practices in terms of crop intensification versus crop monoculture, which are the major management trends in the Pampean region (Viglizzo et al., 2010). Also, these indicators should be sensitive enough to detect early shifts in soil quality as a consequence of soil structural degradation, as this is one of the main problems affecting sustainability in this region (Alvarez et al., 2009, 2014; Sasal, 2012). The indicators need to give similar trends across different soil types, be easy to understand, not time consuming and cheap enough to be included in periodic soil surveys.

A sensitive indicator in widespread use to evaluate the physical response of soil to management is aggregate stability (Kay, 1990; Perfect et al., 1990; Bonel et al., 2005; Sanzano et al., 2005). This is a particularly interesting soil property because it is linked to environmental quality (e.g. C sequestration, water quality, regulation of greenhouse emissions) (Bronick and Lal, 2005; Chenu et al., 2000; Rosa et al., 2014) and crop productivity (e.g. root development, water availability and air and water dynamics) (Hermawan and Cameron, 1993). There are several weaknesses in measuring soil aggregate stability. Testing approaches vary between laboratories so results may not be comparable. Aggregate stability is also affected by several soil properties so it is not possible to disentangle underlying mechanisms that may be stabilizing soils.

Aggregate stability depends on aggregation and disruption mechanisms that differ between soil types (Six et al., 2004). Clay mineralogy, calcium and iron content and the amount and quality of organic carbon fractions, among other factors, control the dynamics and extent of aggregate stability (Le Bissonnais, 1996; Cañasveras et al., 2009; Igwe et al., 1999; Denef and Six, 2005). For instance, soils dominated by swelling clays are characterized by low aggregate stability, whereas a mixture of oxides and kaolin clays can lead to very stable aggregation (Burroughs et al., 1992). Soil texture is another major factor influencing aggregate stability, which becomes weaker and more dependent on the organic phase when the proportion of coarser particles increases. In the case of silty soils, microorganisms play a more important role in aggregation compared to the soil mineral phase (Cosentino et al., 2006). Besides, aggregate disruption by water is caused by mechanical breakdown due to the kinetic energy of rain drops, and to the swelling of clay and organic domains causing microcracking and slaking upon rapid wetting. Slaking disrupts aggregates by the forces exerted by compressed air entrapped during rewetting (Le Bissonnais and Le Souder, 1995; Le Bissonnais, 1996). According to Caron (1996), an increased rate of water entry is the major mechanism for decreased aggregate stability, whereas interparticle cohesion and swelling are less important processes (Zaher et al., 2005). Aggregate stability tests proposed by Le Bissonnais (1996) differentiate these mechanisms through fast and slow wetting or mechanical breakdown, allowing for greater interpretation of soil structure formation and stabilization. In silty soils, fast wetting tests have resulted in much greater aggregate disruption than slow wetting, emphasising the importance of water entry on aggregate stability (Cosentino et al., 2006; Chenu et al., 2000; Varela et al., 2010).

One of the driving processes controlling water entry and slaking is soil water repellency. Soil water repellency is the reduction of the affinity of soils to water such that they resist wetting for periods ranging from a few seconds to hours, days or weeks (King, 1981; Doerr and Thomas, 2000). A broad range of water repellency levels (in terms of severity and persistence) exist in soils, with significant environmental impacts (Hallett et al., 2001). Most studies consider water repellency as a negative soil property as it impairs water infiltration, water availability increasing runoff and soil erosion (Jaramillo, 2003). Also water repellency could be associated with the occurrence of uneven wetting patterns, development of preferential flow and the accelerated leaching of agrichemicals (Doerr and Thomas, 2000; Ritsema et al., 1993, Ritsema et al., 1997; White et al., 2000).

Several studies have shown that while most soils appear to be readily wettable, many are actually slightly water repellent, leading to the term 'subcritical water repellency' (Tillman et al., 1989).

Soil management (DeBano, 2000, Hallett et al., 2001) and cropping affects soil water repellency (Dekker and Ritsema, 1997). Under NT, water repellency has been found to be higher compared to conventional tillage (Chan, 1992, Simon et al., 2009; Blanco-Canqui and Lal, 2009; Blanco-Canqui, 2011). González-Peñaloza et al. (2012) found changes in soil water repellency within one or two years of changes in soil management, but data on subcritical water repellency as affected by NT management remains scarce. Under NT, the absence of soil disturbance and the presence of organic matter provides favourable conditions that increase soil water repellency (Chan, 1992). Soil management practices that increase soil organic $\mathrm{C}$ content generally increase subcritical water repellency (Harper et al., 2000; McKissock et al., 2002). Soil water repellency is affected by intrinsic soil properties such as type, texture and mineralogy (Jaramillo, 2003; Dlapa et al., 2004). Coarse minerals decrease specific surface area so generally enhance soil water repellency (Wallis and Horne, 1992; De Gryze et al., 2006) but not always (Doerr et al., 2000; Vogelmann et al., 2013).

Several studies have correlated aggregate stability with soil water repellency (Chenu et al., 2000; Hallett et al., 2001; Mataix-Solera and Doerr, 2004), but sometimes the relationships are poor (Cosentino et al., 2006). In a pasture field experiment, De Gryze et al. (2006) found that $R_{\text {index }}$ was not significantly correlated with macroaggregation $\left(\mathrm{R}^{2}=0.20, P>0.05\right)$. Moreover, according to Vogelmann et al. (2013) only in drier periods when the soil becomes more water repellent the effect on aggregate stability is expected to be positive. Thus, assuming a direct link to water repellency is probably too simplistic because so many factors affect soil aggregate stability (e.g. soil texture, organic carbon fractions, clay mineralogy).

This study uses soils from the A horizon of Pampean soils to explore the impact of soil management on a range of properties to assess potential links between soil water repellency and aggregate stability. It builds on previous research by including a broad range of textures, mineralogy and management so that multiple soil properties that control aggregate stability, in addition to soil water repellency, can be explored. We hypothesize that soil aggregate stability will be mainly dependent on the quantity and quality of OM fractions and on soil water repellency, which in turn will depend on soil management. The objective of this study is to evaluate soil water repellency as an indicator of crop management impact for some soil types in the Pampas region (Argentina), comparing also the results found with the water drop penetration time (WDPT) test and the repellency index, $R_{\text {index }}$. This research helps to unravel driving mechanisms of soil aggregate stabilization as affected by soil management, with an aim to assess 
Table 1

Good and poor agricultural practices (GAP and PAP, respectively) for the four selected soils for the 2004-2010 period.

\begin{tabular}{|c|c|c|c|c|c|c|c|c|}
\hline \multirow[t]{2}{*}{ Soil treatment } & \multicolumn{2}{|c|}{$\begin{array}{c}\text { Haplustoll } \\
\text { (General Cabrera series) }\end{array}$} & \multicolumn{2}{|c|}{$\begin{array}{c}\text { Argiudoll } \\
\text { (Monte Buey series) }\end{array}$} & \multicolumn{2}{|c|}{$\begin{array}{c}\text { Argiudoll } \\
\text { (Pergamino series) }\end{array}$} & \multicolumn{2}{|l|}{$\begin{array}{c}\text { Hapludert } \\
\text { (Santiago series) }\end{array}$} \\
\hline & GAP & PAP & GAP & PAP & GAP & PAP & GAP & PAP \\
\hline $2004 / 2005$ & $\begin{array}{l}\text { Wheat/ } \\
\text { Soybean }\end{array}$ & Peanut & Wheat/Sorghum & Soybean & Soybean & Soybean & Wheat/Soybean & Maize \\
\hline $2005 / 2006$ & Maize & $\begin{array}{l}\text { Wheat/ } \\
\text { Soybean }\end{array}$ & Maize & $\begin{array}{l}\text { Wheat/ } \\
\text { Soybean }\end{array}$ & $\begin{array}{l}\text { Wheat/ } \\
\text { Soybean }\end{array}$ & Soybean & Sweet clover + Rye-Grass/Maize & Soybean \\
\hline $2006 / 2007$ & $\begin{array}{l}\text { Wheat/ } \\
\text { Soybean }\end{array}$ & Soybean & Wheat/Soybean & Maize & Maize & Soybean & Soybean & $\begin{array}{l}\text { Wheat/ } \\
\text { Soybean }\end{array}$ \\
\hline $2007 / 2008$ & Vetch/Maize & $\begin{array}{l}\text { Wheat/ } \\
\text { Soybean }\end{array}$ & $\begin{array}{l}\text { Vetch/Maize- } \\
\text { Soybean }\end{array}$ & Soybean & Soybean & Soybean & Wheat/Soybean & Maize \\
\hline $2008 / 2009$ & $\begin{array}{l}\text { Wheat/ } \\
\text { Soybean }\end{array}$ & Soybean & Maize & Soybean & $\begin{array}{l}\text { Wheat/ } \\
\text { Soybean }\end{array}$ & Soybean & Maize & Soybean \\
\hline $2009 / 2010$ & Soybean & Soybean & Wheat/Soybean & Soybean & Maize & Soybean & Soybean & Soybean \\
\hline ISI $_{\text {agr }}{ }^{\mathrm{a}}$ & 0.67 & 0.53 & 0.64 & 0.49 & 0.56 & 0.42 & 0.59 & 0.50 \\
\hline Years under No-Till & 13 & 5 & 28 & 10 & 6 & 5 & 13 & 9 \\
\hline Soybean/Crops ratio ${ }^{\mathrm{b}}$ & 0.40 & 0.62 & 0.28 & 0.75 & 0.50 & 1.00 & 0.44 & 0.57 \\
\hline Maize/Crops ratio ${ }^{\mathrm{b}}$ & 0.20 & 0.00 & 0.30 & 0.14 & 0.25 & 0.00 & 0.22 & 0.28 \\
\hline Soybean/Maize ${ }^{c}$ & 4 & 5 & 1 & 5 & 2 & 6 & 2 & 2 \\
\hline $\begin{array}{l}\text { Soybean as only crop } \\
(\%)^{\mathrm{d}}\end{array}$ & 0.17 & 0.50 & 0.00 & 0.66 & 0.33 & 1.00 & 0.33 & 0.50 \\
\hline
\end{tabular}

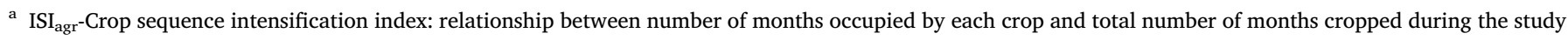
period.

b Number of soybean or maize crops in relation to total crops during the study period.

c Number of soybean crops related to maize crops (soybean/maize).

d Number of soybean as the only crop in the year.

water repellency measurements as a sensitive, simple and quantitative indicator.

\section{Material and methods}

\subsection{Soils and management}

Four soils under no-till cultivation and two different management practices (GAP: good agricultural practices; PAP: poor agricultural practices), were studied (Table 1 ). These were compared with a reference system designated as Natural Environment (NE), consisting of natural grassland that had not been tilled for at least 30 years, located $<5 \mathrm{~km}$ from the sampling area of GAP and PAP treatments. Information about soil management can be found in Figuerola et al. (2012), Rosa et al. (2014) and Kraemer (2015). Separating GAP and PAP was based on criteria described by the Certification in Good Agricultural Practices program of AAPRESID (2013) and the guidelines of Good Agricultural Practices (2013) developed by the Food and Agricultural Organization of the United Nations. GAP was characterized by intensive crop sequences (more crops during the year mainly due to the inclusion of winter crops), a low ratio between soybean crops and total crops, high stubble cover, targeted fertiliser placement and efficient use of agrochemicals (herbicides, pest control). PAP was characterized by a lower crop diversification close to monocultures (a high ratio between soybean crops and total crops), with broadcast fertiliser, high use of agrochemicals, and lower yields. Based on Aapresid criteria and Derpsch et al. (2014), only GAP follows all of the NT system assumptions (diverse crop rotation, optimal use of agrochemical, pests control, etc.)

Several management variables quantified the impact of management on the soils, providing a management index (Management_CP1) constructed using multivariate analyses (principal component analyses, PCA), with the major components listed in Table 1. When the Natural Environment NE was included in the analysis, the variable ISI ${ }_{\text {agr }}$ was recalculated and a value of 1 was used to reflect all year soil use (ISI).

The four sites were along a west-east transect in the northern part of the Argentinean Pampas, comprising three Mollisols and one Vertisol from a range of locations. The Mollisols were General Cabrera series in
Bengolea (Córdoba province), a sandy loam Entic Haplustoll $\left(33^{\circ} 01^{\prime}\right.$ $31^{\prime \prime} \mathrm{S}$; $63^{\circ} 37^{\prime} 53^{\prime \prime} \mathrm{W}$ ); Monte Buey series in Monte Buey (Córdoba province), a Typic Argiudoll with a moderately developed illuvial Bt horizon that had increased proportion of the silt fraction $\left(32^{\circ} 58^{\prime} 14^{\prime \prime} \mathrm{S}\right.$; $62^{\circ} 27^{\prime} 06^{\prime \prime} 1 \mathrm{~W}$ ); Pergamino series, in Pergamino (Buenos Aires province), a silty loam Typic Argiudoll with a well-developed Bt horizon $\left(33^{\circ} 56^{\prime} 36^{\prime \prime} \mathrm{S} ; 60^{\circ} 33^{\prime} 57^{\prime \prime} \mathrm{W}\right)$. The Vertisol was Santiago series in Viale (Entre Ríos province), a silty clay loam Hapludert ( $31^{\circ} 52^{\prime} 59,6^{\prime \prime} \mathrm{S} ; 59^{\circ}$ $\left.40^{\prime} 07^{\prime \prime} \mathrm{W}\right)$. The annual precipitation decreases from the east to the west (1023 mm to $795 \mathrm{~mm}$ (SMN, 2012) with rain concentrated during spring and summer periods. The temperature follows a longitudinal trend with means varying from $18.0^{\circ} \mathrm{C}$ to $16.3^{\circ} \mathrm{C}$.

\subsection{Aggregate stability}

Sampling was done in winter at least two months after summer crop harvest and before seeding to minimize both effects on soil structure. In all sites, rainfall was low in the three months previous to sampling (Supp. Fig. 1). Three undisturbed soil cores $\left(3300 \mathrm{~cm}^{3}\right)$ were taken from the topsoil ( 0 to $0.15 \mathrm{~m}$ ) in each of three sub-plot areas located in each production plot, accounting for a total of 9 samples by sample unit (combination between soil/management treatment). Soil samples were transported to the laboratory where they were manually broken through their planes of weakness at field capacity and sieved to obtain aggregates between 3 and $5 \mathrm{~mm}$.

Aggregate stability, expressed as Mean Weight Diameter (MWD) was determined using the three approaches developed by Le Bissonnais (1996): (i) $M W D_{\text {fast: }}$ : Fast wetting; (ii) MWD $_{\text {stir: }}$ stirring in water after submersion in ethanol; and (iii) $\mathrm{MWD}_{\text {slow: }}$ slow wetting, with these data aggregated to obtain the $\mathrm{MWD}_{\text {mean }}$. We also incorporated an extra test, $M W D_{\text {fast10s, }}$, where the time of rapid wetting was limited to $10 \mathrm{~s}$ as opposed to $10 \mathrm{~min}$ to assess the early slaking processes (Kraemer et al., 2012; Kraemer, 2015). Le Bissonnais aggregate stability tests were used here to obtain a better discrimination between the disaggregation mechanisms to water: (i) slaking (with the fast wetting test); (ii) cohesion without slaking (stirring aggregates after ethanol submersion) and (iii) microcraking without slaking (with the slow wetting test). 


\subsection{Soil water repellency determinations}

Soil water repellency was measured using the WDPT and $R_{\text {index }}$. WDPT describes the persistence of water repellency from the time taken for a drop of water to penetrate the soil (Letey, 1969). $R_{\text {index }}$ measures the water repellency levels at the onset of wetting, based on direct measurement of liquid infiltration rates of water and a wettable liquid (ethanol) not influenced by hydrophobicity. Both methodologies were carried out on the same $3-5 \mathrm{~mm}$ aggregates.

WDPT measures the time taken for $3 \mu \mathrm{L}$ of deionized water to enter the surface of an aggregate. This was determined on 15 aggregates for each of GAP, PAP and NE, resulting in 45 determinations per soil type. Measurements were performed under a stereo-microscope (Wild MZ8 Leica) with a micro-syringe Hamilton CR 700-200. During the measurements the ambient temperature was $25 \pm 2{ }^{\circ} \mathrm{C}$ and relative humidity was $60 \pm 5 \%$. Aggregates were oven-dried at $50^{\circ} \mathrm{C}$. Oven-dried aggregates were used to eliminate the effect of different soil moisture contents on water repellency (Dekker et al., 2001) and to asses potential water repellency as this temperature is often attained by bare soils during hot summers (Doerr and Thomas, 2000). WDPT was also measured at $20^{\circ} \mathrm{C}$, but no differences were found to $50{ }^{\circ} \mathrm{C}$ drying so the results are not used in the analyses.

The $\mathrm{R}_{\text {index }}$ was measured with a microinfiltrometer device according Hallett and Young (1999) from the sorptivity of individual aggregates (3-5 $\mathrm{mm}$ ) to deionized water and ethanol ( $96 \%$ vol). Liquids were supplied to the aggregates through a micropipette tip with a $140 \mu \mathrm{m}$ radius from a source at constant hydraulic head $(\Psi=-3 \mathrm{~cm})$. Mean elapsed time of each sorptivity measurement was two minutes. Sorptivity, $S\left(\mathrm{~mm} \mathrm{~s}^{-1 / 2}\right)$ was calculated by:

$S=\sqrt{\frac{Q f}{4 r b}}$

where $Q$ is the liquid flow $\left(\mathrm{mm}^{3} \mathrm{~s}^{-1}\right), f$ is the air-filled porosity $\left(\mathrm{m}^{3} \mathrm{~m}^{-3}\right), r$ is the radius of the infiltrometer tip $(\mathrm{mm})$ and $\mathrm{b}=0.55 . f$ was measured by immersing samples in kerosene and measuring Archimedes' force according to Monnier et al. (1973) so that porosity could be calculated from bulk density and particle density. Particle density was measured by the pycnometer method (Blake and Hartge, 1986) with kerosene as non-polar liquid.

From $S$ of water, $S_{w}$ and ethanol, $S_{e}, \mathrm{R}_{\text {index }}$ can be calculated by:

$R_{\text {index }}=1.95 \frac{S_{\text {ethanol }}}{S_{\text {water }}}$

with the constant 1.95 accounting for differences in the surface tension and viscosity between liquids. The apparent soil water contact angle (Contact angle $\theta$ ) was derived from $R$ (3).

Contac angle $\Theta=\arccos \frac{1}{R}$

Water and ethanol sorptivities were measured on 15 aggregates for each sample unit.

\subsection{Organic carbon fractions}

Soil organic carbon (SOC) was determined by dry combustion (LECO, St. Joseph, MI, USA). The samples were first air-dried and passed through a $2000 \mu \mathrm{m}$ sieve. Soil organic fractionation by particle size was conducted using the method described by Duval et al. (2013). Briefly, a wet sieving was done with a pair of sieves of 53- and $105-\mu \mathrm{m}$ diameter mesh to obtain three fractions: the coarse fraction $(105-2000 \mu \mathrm{m})$ containing coarse particulate organic carbon $\left(\mathrm{POC}_{\mathrm{c}}\right)$ and fine to coarse sands, the medium fraction $(53-105 \mu \mathrm{m})$ containing fine particulate organic carbon $\left(\mathrm{POC}_{\mathrm{f}}\right)$ and very fine sands, and the fine fraction $(<53 \mu \mathrm{m})$ containing mineral-associated organic carbon (MOC), together with silt and clay. The C content of the particulate labile fractions was determined in the same way as the SOC. The total
POC was assumed to be $\mathrm{POC}_{\mathrm{c}}+\mathrm{POC}_{\mathrm{f}}$. The difference between SOC and total POC was used to calculate the organic carbon content of the < $53 \mu \mathrm{m}$ MOC. The determination of carbohydrates $(\mathrm{CH})$ was performed following the proposed procedure by Puget et al. (1999). Total carbohydrates (CHt) extraction was performed by acid hydrolysis on $1 \mathrm{~g}$ of soil sample that was treated with $10 \mathrm{~mL} 0.5 \mathrm{M} \mathrm{H}_{2} \mathrm{SO}_{4}$, heated at $80^{\circ} \mathrm{C}$ for $24 \mathrm{~h}$. Soluble carbohydrate (CHs) extraction used $1 \mathrm{~g}$ of soil sample that was suspended in $10 \mathrm{~mL}$ of distilled water and heated at $80^{\circ} \mathrm{C}$ for $24 \mathrm{~h}$. After extraction, each suspension was centrifuged at $4000 \mathrm{rpm}$ for 15 min (Puget et al., 1999). Carbohydrate contents were determined using the phenol-sulphuric acid spectrophotometric method with glucose standard curve (Dubois et al., 1956). More information and full organic fractions values can be found at Duval et al., (2013; 2018).

\subsection{Soil characterization}

Bulk composed soils samples were collected in each experimental unit (n: 3) at $0-0.15 \mathrm{~m}$ depth. The following parameters were determined in the crushed and $2 \mathrm{~mm}$ sieved soil samples: particle size distribution, particle density, cation exchangeable capacity, Atterberg limits, clay activity, clay mineralogy, $\mathrm{pH}$, electrical conductivity and exchangeable sodium percentage (Supp. Table 1). All determinations were made by conventional methods. Further information on the methods can be found in Rosa et al. (2014) and Kraemer (2015). The clay mineralogy of the soil surface horizons of the General Cabrera, Monte Buey and Pergamino series was similar, consisting of 2:1 clays, mainly illites with a small proportion of irregular interstratified illitesmectite minerals, and traces of kaolinite. Santiago series was characterized by a considerable proportion of smectite together with lower proportions of illites (Kraemer et al., 2012) (Supp. Table 1).

\subsection{Statistical analyses}

A general linear mixed-effects model was used to determine how aggregate stability $\left(\mathrm{MWD}_{\text {fast10s }}, \mathrm{MWD}_{\text {fast }}, \mathrm{MWD}_{\text {stir }}, \mathrm{MWD}_{\text {cap }}\right.$ and $\mathrm{MDW}_{\text {mean }}$ ) and soil water repellency (WDPT and $\mathrm{R}_{\text {index }}$ ) were influenced by soil type (four levels) and management treatment (three levels: NE, GAP or PAP) as fixed effects and all their interactions. As preliminary analyses showed that the predictor variables affected the variability among sampling units, the models also estimated different variances for each management treatment level in each soil type. In addition, the model included as random effects (random intercepts) the influences of subplots nested within plots and nested within soil types. WDPT was log-transformed to accomplish model assumptions and then retransformed to present in the figure. Descriptive results from WDPT are presented with the median to account this non-normality of data. The model was estimated using the lmer function of the lme4 package (Bates et al., 2011) in R (R Development Core Team 2011).

Linkage between soil water repellency (WDPT and $\mathrm{R}_{\text {index }}$ ) and aggregate stability $\left(\mathrm{MWD}_{\text {fast } 10 \mathrm{~s}}, \mathrm{MWD}_{\text {fast }}, \mathrm{MWD}_{\text {stir }}, \mathrm{MWD}_{\text {slow }}\right.$ and $\mathrm{MDW}_{\text {mean }}$ ) was assessed by linear regression. The effects of soil management indexes, soil characteristics and organic carbon fractions on WDPT were assessed by Pearson correlation. To evaluate the effect of the Hapludert (characterized by smectitic clay mineral and high clay content) on these correlations, a subset was performed removing this soil. To compare different soil water repellency methods (WDPT and $\mathrm{R}_{\text {index }}$ ) Pearson correlation between WDPT and $\mathrm{R}_{\text {index }}$ was performed.

\section{Results}

\subsection{Aggregate stability}

Agricultural production practices (GAP and PAP) had a significant impact on aggregate stability expressed as MWD of soil aggregates, with the least disturbed samples under NE $(2.44 \mathrm{~mm})$ being far more stable than under either GAP $(1.28 \mathrm{~mm})$ or PAP $(0.88 \mathrm{~mm})(P<0.001)$ 

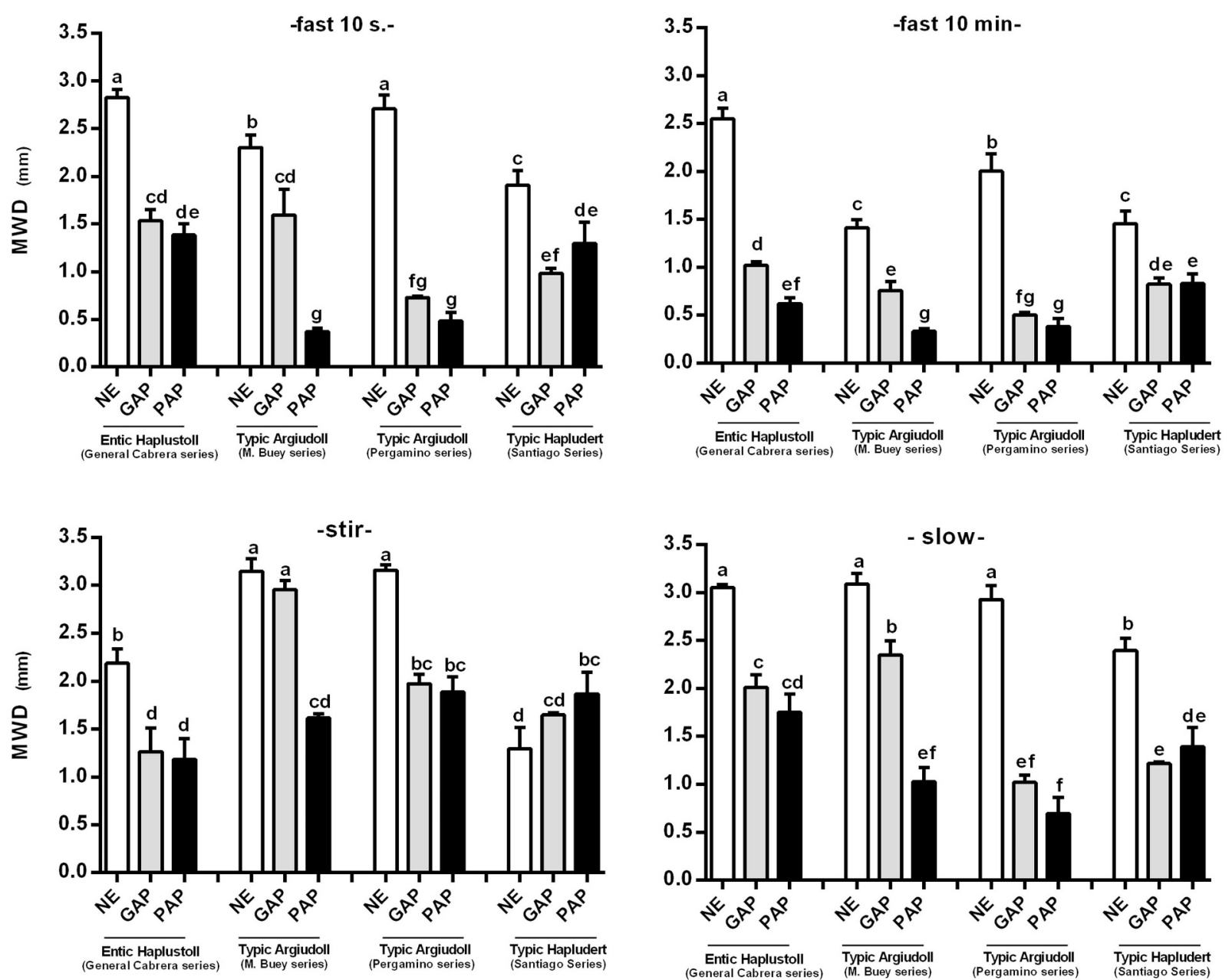

Fig. 1. Aggregate stability tests (MWD: mean weight diameter) for the interaction soil type and treatment (NE: natural environment; GAP: good agricultural practices; PAP: poor agricultural practices) according to Le Bissonnais (1996). Different letters correspond to significant differences for soil type * treatment interaction ( $\mathrm{P}<0.05)$. MWD: mean weighed diameter; fast10s: fast (10s) wetting of aggregates; fast: fast (10 min.) wetting of aggregates; stir: stirring in water after submersion in ethanol; slow: slow wetting of aggregates and mean: mean of previous three variables.

Table 2

$F$ values for each term (fixed) of the model for all aggregates stability tests and soil water repellency measured by WDPT.

\begin{tabular}{lccc}
\hline & Soil type & Treatment & $\begin{array}{c}\text { Soil type* } \\
\text { Treatment }\end{array}$ \\
\hline $\begin{array}{l}\text { Aggregates stability tests } \\
\text { MWD }_{\text {fast10s }}\end{array}$ & $11.9^{* * * *}$ & $152.3^{* * *}$ & $10.9^{* * *}$ \\
MWD $_{\text {fast }}$ & $19.4^{* * *}$ & $147.6^{* * *}$ & $9.2^{* * * *}$ \\
MWD $_{\text {stir }}$ & $40.4^{* * *}$ & $25.2^{* * *}$ & $12.3^{* * *}$ \\
MWD $_{\text {slow }}$ & $31.6^{* * * *}$ & $175.3^{* * * *}$ & $9.2^{* * *}$ \\
MWD & $163.4^{* * *}$ & $15.9^{* * *}$ \\
Soil water repellency & $29.4^{* * *}$ & & $8.75^{* * *}$ \\
WDPT & $219.1^{* * *}$ & $93.6^{* * *}$ &
\end{tabular}

*** $P<0.001$. WDPT: Water drop penetration time. MWD: mean weighed diameter; fast10s: fast (10 s) wetting of aggregates; fast: fast (10 min.) wetting of aggregates; stir: stirring in water after submersion in ethanol; slow: slow wetting of aggregates and mean: mean of previous three variables.

across all soil types (Fig. 1). However, there was a significant interaction between soil type and land management impacts on all aggregate stability tests (Table 2), with the greatest differences between treatments in the Argiudoll (Monte Buey series) followed by the Haplustoll and the Argiudoll (Pergamino series) (Fig. 1). Although for most soils and management approaches the MWD decreased in the order of NE, to GAP and then to PAP, the Vertisol sometimes behaved differently for particular MWD tests (Fig. 1). For instance, the opposite trend was found with $M W D_{\text {stir }}$.

Overall, aggregate stability tests differ in their efficiency to discriminate agricultural management practices. Clearer differences were obtained with the fast wetting test followed by fast wetting 10 s and slow wetting, with stirring after prewetting test detecting the least differences due to land management (Fig. 1). Comparing the results from the different tests, for all soils the lowest aggregate stability values were for $\mathrm{MWD}_{\text {fast }}(1.1 \mathrm{~mm})$ followed by $<\mathrm{MWD}_{\text {rap }} 10 \mathrm{~s}(1.5 \mathrm{~mm})<$ $\mathrm{MWD}_{\text {cap }}(1.7 \mathrm{~mm})<\mathrm{MWD}_{\mathrm{ag}}(1.9 \mathrm{~mm})$. As expected, $\mathrm{MWD}_{\text {fast10s }}$ results were strongly correlated with $\mathrm{MWD}_{\text {fast }}$ and both were also strongly correlated with $\mathrm{MWD}_{\text {mean }}$. MWD $\mathrm{M}_{\text {stir }}$ presented the lowest correlation coefficients with the other tests.

\subsection{Soil water repellency-WDPT}

The WDPT test reveals the existence of sub-critical repellency in almost all analysed soils, as $99 \%$ of the values were in the 0-60 s range, from which $46 \%$ were between 0 and $1 \mathrm{~s}$ (data not shown). The linear mixed models presented significant effects of soil type and treatments factors and their interaction $(P<0.001)$. NE had greater WDPT than GAP in three of the four soils assessed, except in the Haplustoll (Fig. 2). For all soils, GAP had higher WDPT values than PAP for all but the Argiudoll (Pergamino series) soils. Land management produced higher variability of the data in respect to soil types, showing high 


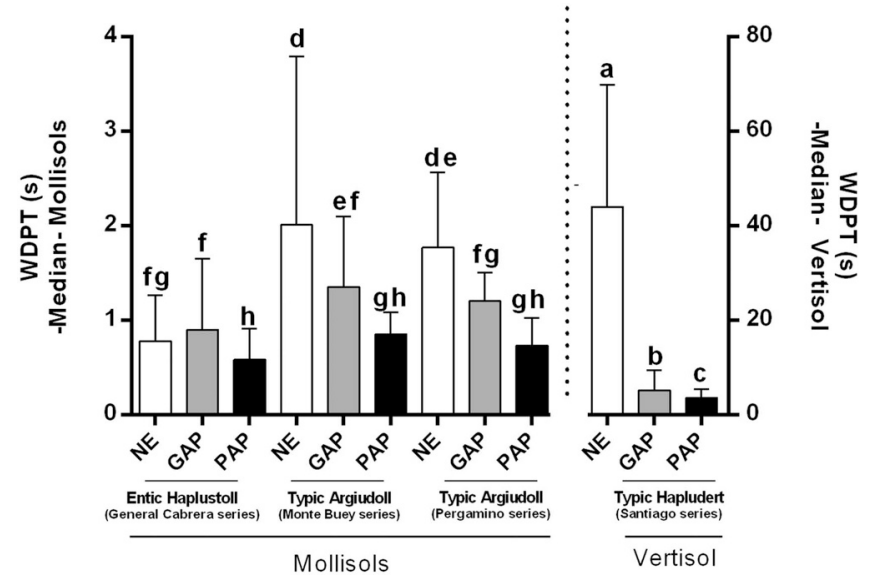

Fig. 2. WDPT (water drop penetration time) average median values for treatments (NE: natural environment; GAP: good agricultural practices; PAP: poor agricultural practices) and soil types. Different letters indicate differences for treatment and soil type interactions. Bars indicate the interquartile ranges.

interquartile ranges in NE and lower ranges in PAP (Fig. 2).

The highest WDPT values were found in the Hapludert and the lowest in the Haplustoll, while both Argiudolls showed intermediate values. $(P<0.05)$ (Fig. 2). The median WDPT values for all treatments were $0.75 \mathrm{~s}$ for the Haplustoll, $1.20 \mathrm{~s}$ for the Argiudoll (Pergamino series), $1.37 \mathrm{~s}$ for the Argiudoll (Monte Buey series) and $6.18 \mathrm{~s}$ for the Hapludert. According to King (1981) all soils fell into the category of very low water repellency (1-10s) and no repellency $(<1 \mathrm{~s})$. Most of the PAP treatments were classified as non-repellent. According to Doerr (1998) all soils fall into the wettable category.

\subsection{Water and ethanol sorptivity and $R_{\text {index }}$}

Water and ethanol sorptivities and $R_{\text {index }}$ results are presented in Fig. 3. The mean values of $S_{\text {water }}$ and $S_{\text {ethanol }}$ for all soils were 0.56 and $0.50 \mathrm{~mm} \mathrm{~s}^{-1 / 2}$ respectively; from Eq. (2) arises a mean $R_{\text {index }}$ value of 1.78 , equivalent to a contact angle of $53.7^{\circ}$. For the three Mollisols, the $\mathrm{R}_{\text {index }}$ of treatments was greatest for NE, followed by GAP and least for PAP. However, the Hapludert had a different trend, with PAP having the highest $R_{\text {index }}$ value (Fig. 3 ). Considering each soil individually, the $\mathrm{R}_{\text {index }}$ trend was: Haplustoll $>$ Argiudoll (Monte Buey series) $>$ Argiudoll (Pergamino series) $>$ Hapludert (Fig. 3). The highest $\mathrm{R}_{\text {index }}$ value was found in NE of the Haplustoll (2.21), whereas the lowest

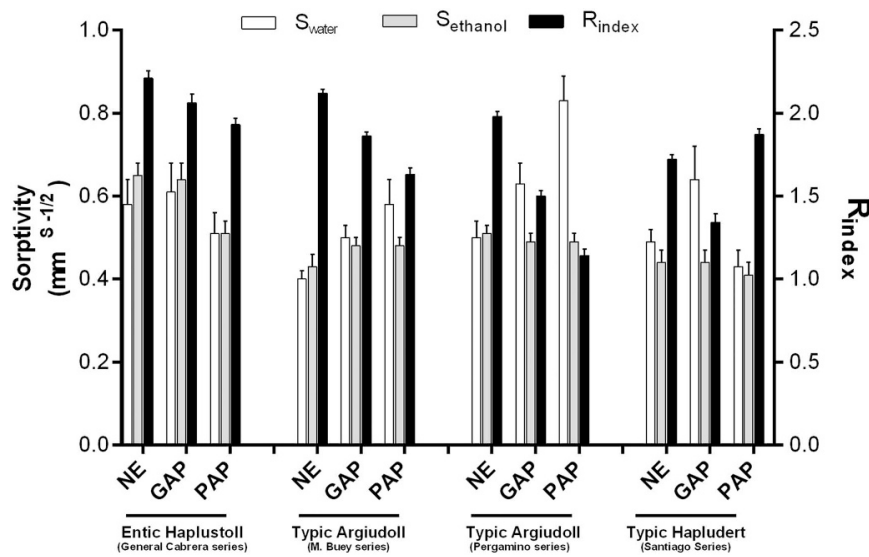

Fig. 3. Soil infiltration and water repellency measured by the micro-infiltrometer method: water sorptivity $\left(S_{\text {water }}\right)$, ethanol sorptivity $\left(S_{\text {ethanol }}\right)$ and water repellency index $\left(R_{\text {index }}\right)$ for the combination of soils and treatments (NE: natural environment; GAP: good agricultural practices; PAP: poor agricultural practices). The standard error is shown.
Table 3

Pearson correlation between aggregates stability tests and soil water repellency measured by WDPT and $\mathrm{R}_{\text {index }}$.

\begin{tabular}{|c|c|c|c|c|}
\hline \multirow[t]{2}{*}{ Data set } & \multicolumn{2}{|c|}{ WDPT } & \multicolumn{2}{|c|}{$\mathrm{R}_{\text {index }}$} \\
\hline & All soils & Mollisols & All soils & Mollisols \\
\hline \multicolumn{5}{|c|}{ Aggregate stability } \\
\hline $\mathrm{MWD}_{\text {fast10s }}$ & $0.36^{*}$ & $0.77^{* * * *}$ & $0.82^{* *}$ & $0.90^{*}$ \\
\hline $\mathrm{MWD}_{\text {fast }}$ & $0.40^{*}$ & $0.73^{* * *}$ & $0.65^{*}$ & $0.70^{*}$ \\
\hline MWD $_{\text {stir }}$ & ns & $0.61^{* * *}$ & ns & ns \\
\hline $\mathrm{MWD}_{\text {slow }}$ & $0.33^{*}$ & $0.78^{* * * *}$ & $0.84^{* * * *}$ & $0.89^{* * * * *}$ \\
\hline $\mathrm{MWD}_{\text {mean }}$ & ns & $0.81^{* * * *}$ & $0.76^{* *}$ & 0.80 \\
\hline
\end{tabular}

WDPT: Water drop penetration time. MWD: mean weighed diameter; fast10s: fast (10s) wetting of aggregates; fast: fast (10 min.) wetting of aggregates; stir: stirring in water after submersion in ethanol; slow: slow wetting of aggregates and mean: mean of previous three variables.

$$
\begin{aligned}
& \text { *** } P<0.001 . \\
& \text { ** } P<0.01 . \\
& \text { * } P<0.05 \text {. }
\end{aligned}
$$

value corresponded to PAP in the Argiudoll (Pergamino series) (1.14) followed by the GAP of the Hapludert (1.34) (Fig. 3).

\subsection{Relationship between aggregate stability and soil water repellency}

WDPT and $R_{\text {index }}$ were correlated with the results of some of soil aggregate stability tests (Table 3 ). Neither $S_{\text {water }}$ nor $S_{\text {ethanol }}$ presented significant correlation with aggregate stability tests. For Mollisols (Argiudolls and Haplustol), WDPT and $\mathrm{R}_{\text {index }}$ had similar and strong correlations with the MWD $\mathrm{Fast10s}_{\text {s }}$ and $\mathrm{MWD}_{\text {Slow }}$ tests (Table 3). When the Vertisol (Hapludert) was included -All Soils-, WDPT had lower Pearson correlation coefficients with aggregate stability. In contrast, $\mathrm{R}_{\text {index }}$ showed similar correlations for both datasets, not being affected by the inclusion of Vertisols samples. Thus, there was a poor correlation coefficient between WDPT and $\mathrm{R}_{\text {index }}$, particularly for the Vertisol. Mechanical breakdown of aggregates (Stir) presented the lowest coefficients between aggregate stability and repellency, regardless of exclusion of the Vertisol and repellency method (Table 3).

As shown in Fig. 4, for WDPT, Mollisols behaved differently from the Vertisol, and differently between the type of aggregate stability test. In Mollisols, $\mathrm{MWD}_{\text {fast10sec }}$ and $\mathrm{MWD}_{\text {slow }}$ had similar slopes $(P>0.05)$ and similar determination coefficients (Fig. 4). $\mathrm{MWD}_{\text {stir }}$, which involves mechanical agitation rather than rapid wetting, had a much smaller slope and poorer determination coefficient.

\subsection{Soil characteristics, organic fractions and treatments effects on soil water repellency}

WDPT and $R_{\text {index }}$ were further analysed for its correlation with a range of soil characteristics, organic fractions and management histories (Table 4). For WDPT, the Vertisol showed much poorer correlations than the Mollisols (Table 4). In Mollisols, there was a strong effect of management variables, particularly of ISI, ISI agr $_{\text {and }}$ soybean as the only crop in rotation. High ISI and ISI $_{\text {agr }}$ lead to high WDPT, whereas a high percentage of soybean in a crop rotation resulted in lower WDPT values. For the Vertisol, the only significant correlation was found with ISI $(r=0.84, P<0.001)$. One of the strongest correlations between WDPT and the organic carbon fractions for All soils and Mollisols was POC $_{c}$, followed by SOC (Table 4). WDPT (All soils) had significant correlations with clay, I $+\mathrm{S}$ content and clay activity. On the contrary when the Mollisols dataset were assessed, no correlations were found. $\mathrm{R}_{\text {index }}$ had positive correlations with ISI ( $r=0.61$ for All Soils, and $r=0.77$ for Mollisols, $P<0.05)$ and ISI $_{\text {agr }}(r=0.82, \mathrm{P}<0.05)$ for Mollisols. Among organic fractions and soil characteristics, $\mathrm{R}_{\text {index }}$ was only correlated with $\mathrm{POC}_{\mathrm{c}}(r=0.68, \mathrm{P}<0.05)$. 

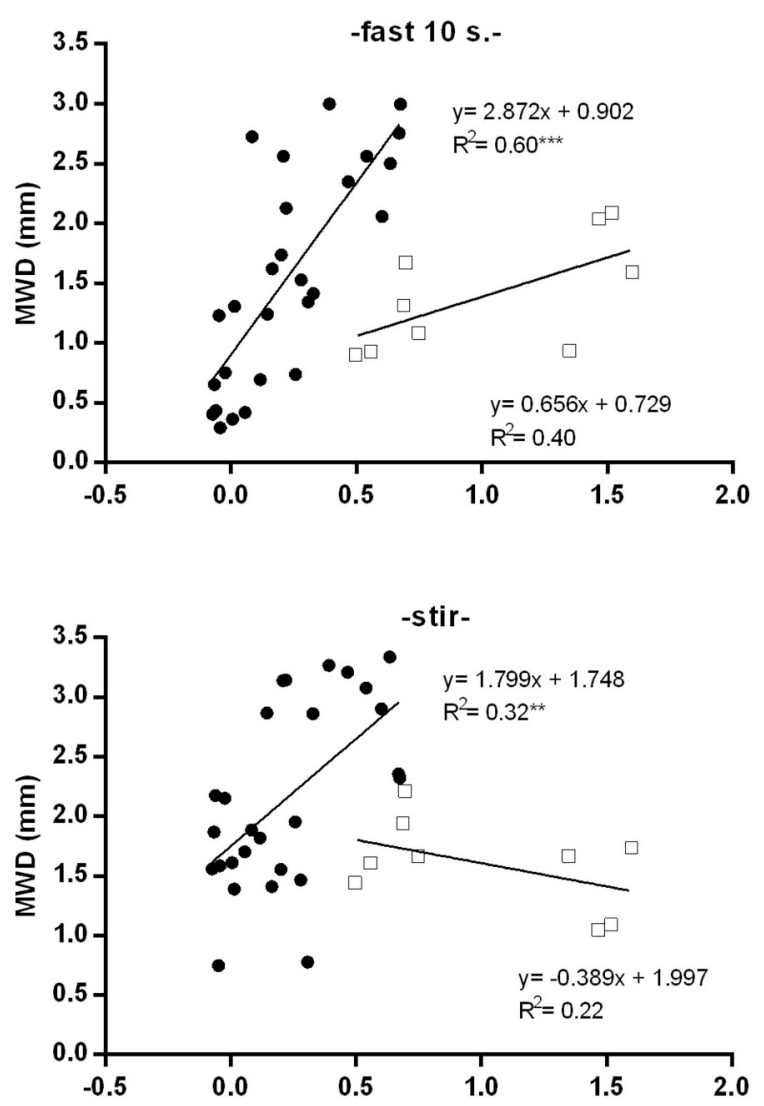
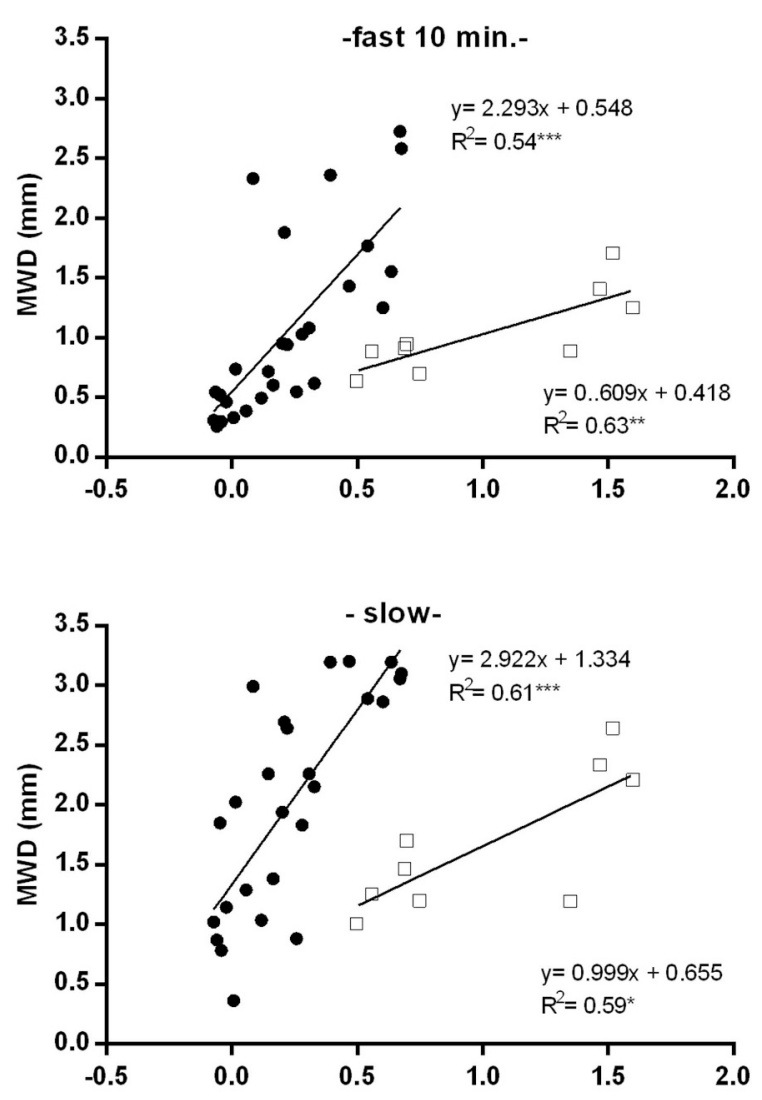

\section{WDPT (log10)}

Fig. 4. Linear regression between soil water repellency measured by WDPT and aggregate stability tests for Mollisols (General Cabrera, Monte Buey and Pergamino series) and the Vertisol (Santiago series). MWD: mean weighed diameter; fast10s: fast (10s) wetting of aggregates; fast: fast (10 min.) wetting of aggregates; stir: stirring in water after submersion in ethanol; slow: slow wetting of aggregates and mean: mean of previous three variables.

Table 4

Pearson correlation coefficients between soil water repellency measured by WDPT in relation to management variables, soil characteristics, organic carbon fractions. Correlations were performed for all soil types (All Soils) and for Mollisols (removing the Hapludert dataset).

\begin{tabular}{|c|c|c|c|c|c|c|c|c|c|c|c|c|c|c|}
\hline \multirow{2}{*}{$\begin{array}{l}\text { Data set } \\
\text { Management variables }\end{array}$} & \multicolumn{2}{|c|}{ All Soils } & \multicolumn{2}{|c|}{ Mollisols } & \multicolumn{3}{|c|}{ All Soils } & \multicolumn{2}{|c|}{ Mollisols } & \multirow[b]{2}{*}{ Organic carbon fractions } & \multicolumn{2}{|c|}{ All Soils } & \multicolumn{2}{|c|}{ Mollisols } \\
\hline & $r$ & $P$ & $r$ & $P$ & Soil characteristics & $r$ & $P$ & $\mathrm{r}$ & $P$ & & $r$ & $P$ & $r$ & $P$ \\
\hline Management_CP1 & -0.44 & * & -0.79 & $* * *$ & Clay & 0.66 & $* * *$ & ns & & SOC & 0.71 & $* * *$ & 0.45 & $* *$ \\
\hline ISI & 0.53 & $* * *$ & 0.83 & $* * *$ & Silt & ns & & & & $\mathrm{POC}_{\mathrm{c}}$ & 0.82 & $* * *$ & 0.80 & *** \\
\hline ISI $_{\mathrm{agr}}$ & ns & & 0.82 & $* * *$ & Sand & -0.41 & * & ns & & $\mathrm{POC}_{\mathrm{f}}$ & 0.63 & ${ }^{* * *}$ & 0.38 & $*$ \\
\hline Years of NT & ns & & 0.59 & $* * *$ & $\mathrm{pH}$ & ns & & ns & & MOC & 0.60 & $* * *$ & ns & \\
\hline Soybean/Crops & -0.44 & * & -0.78 & $* * *$ & CEC & 0.76 & $* * *$ & ns & & $\mathrm{CHs}$ & ns & & 0.42 & * \\
\hline Soybean/Maize & -0.58 & $* *$ & -0.64 & $* * *$ & Clay Activity & 0.64 & $* * *$ & 0.40 & * & $\mathrm{CHt}$ & ns & & 0.68 & $* * *$ \\
\hline Maize/Crops & 0.53 & ** & 0.69 & $* *$ & $S+S / I$ & 0.77 & $* * *$ & ns & & & & & & \\
\hline Soybean only crop & ns & & -0.79 & $* * *$ & & & & & & & & & & \\
\hline
\end{tabular}

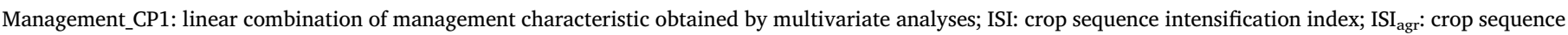

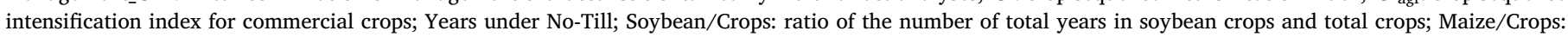

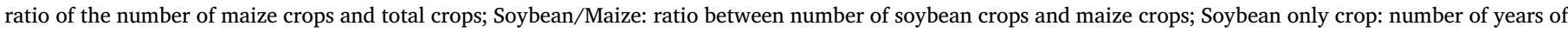

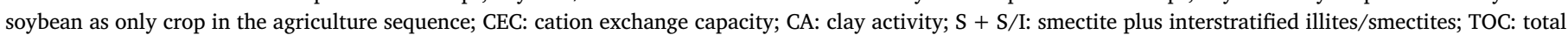

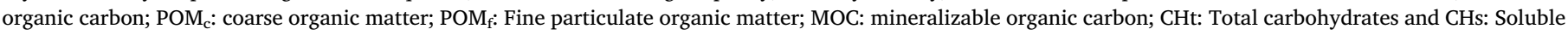
carbohydrates.

*** $P<0.001$.

** $P<0.01$.

$* P<0.05$. 


\section{Discussion}

The range of soil physical indicators evaluated had different sensitivities to changes in soil management. The very simple to apply WDPT test correlated well with the fast-wetting aggregate stability test of Le Bissonnais (1996) and a more rapid $10 \mathrm{~s}$ wetting test, suggesting its potential application as a soil physical quality indicator.

\subsection{Soil water repellency}

WDPT and $\mathrm{R}_{\text {index }}$ discriminated between good and poor agricultural practices regardless of soil type, but the trends differed between Mollisols and Vertisols. There are few studies on subcritical repellency between contrasting management under no-tillage and, to our knowledge, none in South America. Debate remains about the effects of crop intensification under no-tillage (Sasal et al., 2016; Castiglioni et al., 2013) so our findings could help the interpretation of very dynamic soil properties related to biological activity, carbon and water movement.

Crop diversification appears to be a major driver in water repellency development, with the frequency of soybean monocultures having a negative impact due as it reduces water repellency (Table 4 ). $\mathrm{R}_{\text {index }}$ also had strong correlation with ISI and ISI $_{\text {agr }}$ supporting the assumption that the resident time and diversity of living roots is one of the main factors enhancing soil water repellency. This effect is explained by the release of several hydrophobic substances in the rhizosphere (Rougier, 1981). Cosentino et al. (2006) demonstrated the strong, though ephemeral effect, of maize residue on increased soil water repellency measured by the WDPT, $R_{\text {index }}$ and capillary rise methods. Less diverse crop sequences, trending to a soybean monoculture, had small WDPTs. Soybean residues have a low $\mathrm{C} / \mathrm{N}$ that decomposes rapidly and produces little humus compared to maize residue (Ernst et al., 2002), so in the long-term soil water repellency may diminish. The high correlation coefficients between soil water repellency and management variables were enhanced when the Vertisol was removed from the dataset (Table 3) as no significant correlations were found for this soil. The high clay content and smectite clays with high shrink-swell capacity (Supp. Table 1) may overshadow the impact of management practices on soil water repellency in the Vertisol.

Generally, coarse textured soils have greater water repellency (Jaramillo, 2003; Doerr et al., 2000; Harper et al., 2000), although not always (Vogelmann et al., 2010; Doerr et al., 2007; Scott, 2000). Of the soils we studied, the Haplustoll had the coarsest texture but similar water repellency to the finer textured Mollisols tested. A possible explanation is that most of the sand (80\%) was in the fine sand fraction $(50-100 \mu \mathrm{m})$ (data not showed), so specific surface area may be greater than soils in other studies.

On the contrary, we found a 5- to 20-fold higher WDPT values in the Vertisol (Fig. 2), leading to a high correlation between WDPT and clay content when this soil was included (Table 4). This suggests a clay content threshold before a texture effect on soil water repellency occurrence. Dekker et al. (2005) and Doerr et al. (2000) reviewed a range of articles demonstrating soil water repellency in fine-textured soils. For instance, Crockford et al. (1991) found higher soil water repellency in a clayey soil compared to a coarser textured soil. The high soil water repellency values found in the Vertisol studied here were also reported in similar soils by Vogelmann et al. (2010) and Lichner et al. (2006), who also established that the type of clay mineral can influence water repellency. Dlapa et al. (2004) reported an increase in WDPT in Camontmorillonite. Similarly, in sands amended with different types of clays, WDPT increased much more for montmorillonite than kaolinite amended mixtures (Ward and Oades, 1993). Dlapa et al., 2004 proposed that the increase of soil water repellency is related to the tendency to aggregation of high surface clays, such as those found in the studied Vertisol. WDPT into the Vertisol may have been impaired more by pore structure than water repellency, as suggested by the small $S_{\text {ethanol. }}$
When soil water repellency was measured by $R_{\text {index }}$, no effect of soil texture and mineralogy were detected. However, and opposite to WDPT, soil water repellency measured by $R_{\text {index, }}$ increased with sand content. As pointed out by Cosentino (2000) both methods differ strongly regarding the process they assess. In WDPT the pore structure (e.g. size, geometry, tortuosity, continuity), among other features, has an important impact, whereas $R_{\text {index }}$ only measures water repellency.

\subsection{Aggregate stability}

From a range of tests, aggregates destabilized more with less intensification of the crop sequence (Fig. 2). As expected, NE treatments presented the highest stability values because of the greater carbon content (Supp. Table 1), contributed mainly by perennial roots. The intensified crop treatments (GAP) had greater aggregates stability compared to PAP, particularly in Mollisols. As in NE, this could be explained by the longer residing time and greater diversity of living roots (ISI) due to a more diverse and intense crop sequence (lower soybean/crops ratio, higher maize/soybean ratio, Table 1). Soil roots can influence aggregation through binding clay particles by root exudates (Reid and Goss, 1982).

A more diverse crop sequence may also influence aggregate stability due to the amount and quality of crop residues and exudates contributing to different organic carbon fractions (Angers and Caron, 1998). On the contrary, the unfavorable effect of a higher soybean/crop ratio could be related to a lower crop residue volume, worse biochemical quality, lower phenol concentration and lower fauna activity. Other studies performed in the same soils and locations showed a decrease in microorganism community richness and diversity in PAP and thus poorer aggregate stability (Calderoli et al., 2017).

In natural conditions, Vertisols are more affected by microcracking, revealed by $\mathrm{MWD}_{\text {slow, }}$ than Mollisols (Fig. 3, MWD $\mathrm{D}_{\text {slow }}$ ). Microcracking due to smectite in Vertisols is a key mechanism of disaggregation, even in healthy soils, leading to low aggregate stability (Igwe et al., 1999). This could explain the low aggregate stability values found in GAP for the Vertisol due to its high smectite and interestratified I/S content compared to the Mollisols (Supp. Table 1).

Other mechanisms also affect aggregate stability. There appears to be a minimum level of aggregate stability that is related to the cohesion of the clay matrix, regulated by biotic agents that will have some impact on microcracking. In contrast, aggregate stability in Mollisols depends more on biotic agents, so for this soil there is greater discrimination between agricultural practices and natural soils. This reflects the different root and microbial activity, and carbon compounds between the three treatments studied. Differences due to land management were less evident in the Vertisol, reinforcing the dominance of abiotic factors in the aggregate stability of Vertisols compared to Mollisols (Igwe et al., 1999; Six et al., 2004; Novelli et al., 2013).

\subsection{Aggregates stability and soil water repellency}

While the low water repellency $\left(R_{\text {index }}<2.5\right)$ suggests limited impact to infiltration and runoff (Dekker and Ritsema, 1994), this slight change appears to have a positive effect on aggregate stability under rapid wetting, agreeing with trends observed by Vogelmann et al. (2013), Mataix-Solera et al. (2011), Chenu et al. (2000) and Ellies et al. (1996). Similar results were found by Cosentino et al. (2006) in another silty soil of the Pampean region, where a correlation coefficient of $r=0.82$ was obtained between WDPT and $\mathrm{MWD}_{\text {fast }}$ (slaking). Based on the findings by Caron (1996), increased $M_{W} D_{\text {fast10s }}$ with increased WDPT could be related to a decrease in the build-up of air pressure due to slower water entry into more water repellent soil aggregates. The higher determination coefficients and slopes of $\mathrm{MWD}_{\text {fast10s }}$ compared to $\mathrm{MWD}_{\text {fast }}$ could be explained by the fragility of the A horizon of the Mollisols studied, which are characterized by a large silt content with abundant phytoliths and volcanic glasses (Kraemer, 2015) that lead to 
structural instability (Wischmeier et al., 1971; Cosentino and Pecorari, 2002).

Soil aggregates were most stable to the $\mathrm{MWD}_{\text {stir }}$ test, where the prewetting with ethanol prevents slaking due to trapped air (Amézketa, 1999). MWD $_{\text {stir }}$ is less affected by slaking but it also correlated with WDPT, likely because of the impact of organic compounds to both water repellency and the mechanical cohesion of particles.

\subsection{Organic carbon fractions and soil water repellency}

Similar to results reported by Dekker et al. (1998), Täumer et al. (2005), and others, WDPT results obtained in this work were closely related to SOC (Table 4). It has been demonstrated that management practices that increase soil organic carbon content may increase water repellency and decrease wettability (Harper et al., 2000; McKissock et al., 2002). This has been demonstrated in numerous studies, including Cosentino et al. (2010) who found greater soil water repellency after adding maize residue to soil, and Chenu et al. (2000) who found that POC imparts water-repellent characteristics to clays. In our study, the organic matter quality impact was observed in the stronger correlation of POCc rather than SOC or MOC to WDPT (Table 3). POMc is related to newly incorporated carbon due to crop residue (above and below ground), whereas MOC is related to more stabilized carbon. This suggests that the impact of organic carbon on soil water repellency is fast and closely related to crops selection in the agricultural rotation. Moreover, Mollisols studied here showed high and positive correlations between WDPT and the most labile soil OC fractions ( $\mathrm{CHs}$ and $\mathrm{CHt}$ ), both linked with biological activity in soils (Wander, 2004). In the Vertisol, immobilization of those labile organic fractions by adsorption on clay surfaces could decrease impacts on water repellency, hence the better correlations when this soil was excluded from analysis.

The greater insight obtained in this study from assessing different organic carbon fractions, was not observed by Vogelmann et al. (2009), Urbanek et al. (2007), Jaramillo (2006), De Gryze et al. 2006 or Wallis and Horne (1992). Many reasons may explain these divergences, but the type and quality of organic matter and its interaction with a specific composition of the mineral fraction -all of that related to particular ecological conditions and agricultural systems could be a primary driver (Capriel et al., 1990; Becerra, 2006). For instance, Although Urbanek et al. (2007) found high organic carbon and $\mathrm{R}$ values in the grasslands, no direct relationship was found between water repellency and organic carbon content, or the amount of hydrophobic and hydrophilic functional carbon. The authors suggested that structural composition and arrangement of hydrophobic organic compounds may change according the level of hydratation and the existence or not of an organic carbon spatial gradient from the external to internal of an aggregate must also be taken into account.

\subsection{Soil water repellency as a quality indicator}

The results found here, and in accordance with the results of other researches (Peñaloza Gonzalez, et al., 2013; Vogelmann et al., 2013; De Gryze et al., 2006; Chenu et al., 2000) show an important link between aggregate stability, organic carbon and soil water repellency. Even when all soils and treatments WDPT were classified as wettable by Doerr (1998), this rather small differences in seconds found between soils and treatments affects greatly soil aggregate stability. Our findings suggest that in the Mollisols studied, organic carbon fraction played a more important role than texture in subcritical water repellency. This supports an argument that soil water repellency is one of the main properties of soil that influences soil structure stabilization, so could provide a very valuable soil quality indicator. There are many approaches to assess soil water repellency, but to be used most effectively as a quality indicator, a test needs to be reliable, fast and easy to implement.

Compared to other testing approaches, WDPT offers the greatest promise as it can be implemented easily in periodic surveys on the evolution of soil health status. This assumption relies on WDPT being highly correlated with POCc, which in turn is highly dynamic and strongly affected by agricultural practices (Duval et al., 2013).

However, WDPT varies considerably, (Fig. 2), caused by a heterogeneous organic matter distribution in the soil matrix (Chenu et al., 2000) and time-dependent changes in soil porosity during a growing season or due to storage, handling or drying conditions (Cosentino et al., 2010). Thus, the sampling time during the year, and handling of the sample could induce a high dispersion of soil water repellency results, impairing the use of WDPT as a stable soil quality indicator. In our work, the WDPT variability decreases from NE to PAP, which could be attributed to a soil homogenization effect of the agricultural practices. Thus, instead of considering WDPT variability between aggregates as a weakness of the method, it may be taken as an indicator of the management quality. Various processes may decrease WDPT variability under intensive agriculture production, including mixing by tillage and diminished biological abundance and diversity. For the same fields monitored in this study, monocropping in the PAP treatments was linked to homogenization of bacterial diversity at a regional level by losing endemic bacterial groups (Figuerola et al., 2015).

Data reported here are for soils sampled after a long dry period, when water repellency would be expected to be greatest. This agrees with Vogelmann et al. (2013) who found greater effects of water repellency on aggregates stability after dry periods. Further research exploring seasonal variation, taking into account the effect of soil moisture, wetting/drying history, and the presence of crops is required. In addition, subcritical WDPT presents extremely low values in agricultural soils, so there is a need to develop a more sensitive protocol to ensure correct faster sample evaluations. There is scope to modify the more sensitive $R_{\text {index }}$ with simpler, automated infiltrometers (Gordon and Hallett, 2014).

\section{Conclusions}

This study showed the effect of crop intensity on aggregate stability and soil water repellency of different Pampean soils. In general, greater aggregate stability and soil water repellency values were measured in the non-cultivated treatments (NE). This was followed by intensified agricultural treatments (GAP) in the Mollisols, which had greater aggregate stability and water repellency than management close to monocultures (PAP). Soil water repellency, measured either as WDPT or $\mathrm{R}_{\text {index }}$, was highly correlated with aggregate stability tests related to slaking $\left(M W D_{\text {fast10s }}\right.$ and $\left.M W D_{\text {fast }}\right)$. When management treatments in the Vertisol were also included in this analysis, the correlations were weaker but still positive, probably due to the presence of swelling smectite clays that affect microcracking. The results demonstrate an important link between the impacts of organic compounds on both aggregate stability and soil water repellency, suggesting slowed wetting reducing slaking as one of the main stabilization mechanisms of soil structure. The inclusion of the Vertisol in this research highlights the importance of considering inherent soil characteristics such as soil texture and mineralogy. It demonstrates a danger in applying catch-all indicators across a broad range of soils, where the impacts of abiotic versus biotic factors could undermine assessments of 'soil quality' from a small number of variables. However, the high correlation between soil water repellency, organic carbon fractions and aggregate stability suggests WDPT or the $R_{\text {index }}$ provide promise as part of a suite of soil health indicators, demonstrated here for pampean soils under no-tillage.

Supplementary data to this article can be found online at https:// doi.org/10.1016/j.geoderma.2019.113902.

\section{Acknowledgments}

Marine Empson, intern from Agro-Paris Tech for sample collection and help in laboratory measurements. 


\section{Funding}

This work was supported by Facultad de Agronomía, Universidad de Buenos, INTA (Instituto Nacional de Tecnología Agropecuaria) and CONICET (Consejo Nacional de Investigaciones Científicas y Técnicas). This research was part of the BIOSPAS consortium project from ANPCyT (PAE 36976).

\section{References}

AAPRESID, 2013. http://www.aapresid.org.ar/ac/buenas-practicas-agricolas/, Accessed date: 1 October 2018.

AAPRESID, 2017. http://2017.congresoaapresid.org.ar/category/noticias/page/2/, Accessed date: 1 October 2018.

Abid, M., Lal, R., 2009. Tillage and drainage impact on soil quality: II. Tensile strength of aggregates, moisture retention and water infiltration. Soil Tillage Res. 103, 364-372.

Alvarez, C.R., Taboada, M.A., Gutierrez Boem, F.H., Bono, A., 2009. Topsoil properties as affected by tillage systems in the Rolling Pampa Region of Argentina. Soil Sci. Soc. Am. J. 73, 1242-1251.

Alvarez, C.R., Taboada, M.A., Perelman, S., Morrás, H.J.M., 2014. Topsoil structure in notilled soils in the rolling Pampa, Argentina. Soil Res. https://doi.org/10.1071/ SR13281.

Amézketa, E., 1999. Soil aggregate stability: a review. Sust. Agric J. 14, 83-150.

Angers, D.A., Caron, J., 1998. Plant-induced changes in soil structure: processes and feedbacks. Biogeochemistry 42, 55-72.

Bates, D., Maechler, M., Bolker B, 2011. lme4: linear mixed-effects models using S4 classes. R package version 0.999375-39. http://cran.r-project.org.

Becerra, J.C., 2006. Efecto de la matéria orgánica y el manejo sobre la hidrofobicidad de suelos volcánicos. J. Soil Sc. Plant. Nutr. 6 (2), 13-27.

BIOSPAS, 2009. Consortium. http://www.mincyt.gob.ar/_post/descargar.php? idAdjuntoArchivo=22693, Accessed date: 1 March 2019.

Blake, G.R., Hartge, K.H., 1986. Particle density. In: Klute, A. (Ed.), Methods of Soil Analysis, Part 1. Physical and Minerological Methods. Agronomy Monograph No. 9 American Society of Agronomy, Madison, pp. 377-382.

Blanco-Canqui, H., 2011. Does no-till farming induce water repellency to soils? Soil Use Manag. 27, 2-9.

Blanco-Canqui, H., Lal, R., 2009. Corn stover removal for expanded uses reduces soil fertility and structural stability. Soil Sci. Soc. Am. J. 73, 418-426.

Bonel, B., Morras, H., Bisaro, V., 2005. Modificaciones de la microestructura y la materia orgánica en un suelo Argiudol bajo distintas condiciones de cultivo y conservación. Ci. Suelo (Argentina) 23, 1-12.

Bronick, C.J., Lal, R., 2005. Manuring and rotation effects on soil organic carbon concentration for different aggregate size fractions on two soils in northeastern Ohio, USA. Soil Till. Res. 81, 239-252.

Burroughs, E.R.J., Luce, C.H., Phillips, F., 1992. Estimating interrill erodibility of forest soils. Trans. ASAE 35, 1489-1495.

Calderoli, P.A., Collavino, M.M., Kraemer, F.B., Morrás, H.J.M., Aguilar, M., 2017. Analysis of nifH-RNA reveals phylotypes related to Geobacter and cyanobacteria as important functional components of the N2-fixing community depending on depth and agricultural use of soil. Microbiol. https://doi.org/10.1002/mbo3.502. Open doi.

Cañasveras, J.C., Barrón, V., Del Campillo, M.C., Torrent, J., 2009. Estimation of aggregate stability indices in Mediterranean soils by diffuse reflectance spectroscopy. Geoderma. https://doi.org/10.1016/j.geoderma.2009.09.004.

Capriel, P., Beck, T., Borchert, H., Härter, P., 1990. Relationships between soil aliphatic fraction extracted with supercritical hexane and soil microbial biomass, and soil aggregate stability. Sci. Soc. Am. J. 50, 415-420.

Caron, J., 1996. Describing pressure buildup within aggregates following immersion: A model. In: Caron, J. (Ed.), Proceedings of the 3rd Eastern Canada Soil Structure Workshop. Colloque Canadien sur la structure du sol, Merrickville, Ontario, pp. 59-73.

Castiglioni, M.G., Kraemer, F.B., Morrás, H.J.M., 2013. Efecto de la secuencia de cultivos bajo siembra directa sobre la calidad física de suelos de la región Pampeana. Ci. Suelo. 31, 93-105 (Argentina).

Caviglia, O.P., Andrade, F.H., 2010. Sustainable intensification of agriculture in the argentinean pampas: capture and use efficiency of environmental resources. Am. J.Plant Sci. Biotechnol. 3, 1-8.

Chagas, C., Marelli, H., Santanatoglia, O., 1994. Propiedades físicas y contenido hídrico de un Argiudol típico bajo tres sistemas de labranza. Ci. Suelo (Argentina) 12, 11-16.

Chan, K.Y., 1992. Development of seasonal water repellence under direct drilling. Soil Sci. Soc. Am. J. 56, 326-329.

Chenu, C., Le Bissonnais, Y., Arrouays, D., 2000. Organic matter influence on clay wettability and soil aggregate stability. Soil Sci. Soc. Am. J. 64, 1479-1486.

Cosentino, D.J., 2000. Impacto de los limos livianos sobre el comportamiento físico en horizontes superficiales de argiudoles pampeanos. Masters thesis. Escuela para Graduados A. Soriano (FAUBA), Buenos Aires, Argentina.

Cosentino, D., Pecorari, C., 2002. Limos de baja densidad: impacto sobre el comportamiento físico de los suelos de la región pampeana. Ci. Suelo (Argentina) 20, 9-16.

Cosentino, D., Chenu, C., Le Bissonnais, Y., 2006. Aggregate stability and microbial community dynamic under drying-wetting cycles in a silt loam soil. Soil Biol. Biochem. 38, 2053-2062.

Cosentino, D., Hallett, P.D., Michel, J.C., Chenu, C., 2010. Do different methods for measuring the hydrophobicity of soil aggregates give the same trends in soil amended with residue? Geoderma 159, 221-227.
Crockford, S., Topadilis, S., Richardson, D.P., 1991. Water repellency in a dry sclerophyll forest-measurements and processes. Hydrol. Proc. 5, 405-420.

De Gryze, S., Jassogne, L., Bossuyt, H., Six, J., Merckx, R., 2006. Water repellence and soil aggregate dynamics in a loamy grassland soil as affected by texture. Eur. J. Soil Sci. 57, 235-246.

DeBano, L.F., 2000. Water repellency in soils: a historical overview. J. Hydrol. 31, 4-32.

Dekker, L.W., Ritsema, C.J., 1994. How water moves in a water repellent sandy soil. I. Potential and actual water repellency. Water Resour. Res. 30, 2507-2517.

Dekker, L.W., Ritsema, C.J., 1997. Effect of maize canopy and water repellency on moisture patterns in a Dutch black plaggen soil. Plant Soil 195, 339-350.

Dekker, L.W., Ritsema, C.J., Oostindie, K., Boersma, O.H., 1998. Effect of drying temperature on the severity of soil water repellency. Soil Sci. 163 (10), 780-796.

Dekker, L.W., Doerr, S.H., Oostindie, K., Ziogas, A.K., Ritsema, C.J., 2001. Water repellency and critical soil water content in a dune sand. Soil Sci. Soc. Am. J. 65, 1667-1674.

Dekker, L.W., Oostindie, K., Ritsema, C.J., 2005. Exponential increase of publications related to soil water repellency, Aust. J. Soil Res. 43, 403-441.

Denef, K., Six, J., 2005. Clay mineralogy determines the importance of biological versus abiotic processes for macroaggregate formation and stabilization. Eu. J. Soil Sci. 56, 469-479.

Derpsch, R., Friedrich, T., Kassam, A., Li, H., 2010. Current status of adoption of no-till farming in the world and some of its main benefits. Int. J. Agric. Biol. Eng. 3, 1-26.

Derpsch, et al., 2014. Why do we need to standardize no-tillage research? Soil Till. Res. 137, 16-22.

Dlapa, P., Doerr, S.H., Lichner, L., Šír, M., Tesař, M., 2004. Effect of kaolinite and camontmorillonite on the alleviation of soil water repellency. Plant Soil Environ. 50, 358-363.

Doerr, S.H., 1998. On standardizing the 'water drop penetration time' and the 'molarity of an ethanol droplet' techniques to classify soil hydrophobicity: a case study using medium textured soils. Earth Surf. Process. Landf. 23, 663-668.

Doerr, S.H., Thomas, A.D., 2000. The role of soil moisture in controlling water repellency: new evidence from forest soils in Portugal. J. Hydrol. 231-232, 134-147.

Doerr, S.H., Shakesby, R.A., Walsh, R.P.D., 2000. Soil water repellency: its causes, characteristics and hydro-geomorphological significance. Earth Sci. Rev. 51, 33-65.

Doerr, S.H., Ritsema, C.J., Dekker, L.W., Scott, D.F., Carter, D., 2007. Water repellence of soils: new insights and emerging research needs. Hydrol. Proc. 21, 2223-2228.

Dubois, M., Gilles, K.A., Hamilton, J.K., Rebers, P.A., Smith, F., 1956. Colorimetric method for determination of sugars and related substances. Anal. Chem. 28, $350-356$.

Durán, A., Morrás, H., Studdert, G., Liu, X., 2011. Distribution, properties, land use and management of Mollisols in South America. Chin. Geogr. Sci. 21 (5), 511-530.

Duval, M.E., Galantini, J.A., Iglesias, J.O., Canelo, S., Martinez, J.M., Wall, L., 2013. Analysis of organic fractions as indicators of soil quality under natural and cultivated systems. Soil Till. Res. 131, 11-19.

Duval, M.E., Galantini, J.A., Martínez, J.M., Limbozzi, F., 2018. Labile soil organic carbon for assessing soil quality: influence of management practices and edaphic conditions. Catena 171, 316-326.

Ellies, A., Grez, R., Ramirez, C., 1996. Efecto de la materia orgánica sobre la capacidad de humectación y las propiedades estructurales de algunos suelos de la zona centro sur de Chile. Agro Sur 24, 48-58.

Ernst, O., Bentancur, O., Borges, R., 2002. Descomposición de rastrojo de cultivos en siembra sin laboreo: Trigo, maíz, soja y trigo después de maíz o de soja. Agrociencia 6 (1), 20-26.

Figuerola, E.L., Guerrero, L.D., Rosa, S.M., Simonetti, L., Duval, M.E., Galantini, J.A., Bedano, J.C., Wall, L.G., Erijman, L., 2012. Bacterial indicator of agricultural management for soil under no-till crop production. PLoS One 7, e51075.

Figuerola, E.L.M., Guerrero, L.D., Türkowsky, D., Wall, L.G., Erijman, L., 2015. Crop monoculture rather than agriculture reduces the spatial turnover of soil bacterial communities at a regional scale. Env. Microbiol. 17 (3), 678-688.

González-Peñaloza, F.A., Cerdà, A., Zavala, L.M., Jordán, A., Giménez-Morera, A.G., Arcenegui, V., 2012. Do conservative agriculture practices increase soil water repellency? A study in citrus-cropped soils. Soil Till. Res. 124, 233-239.

Good Agricultural Practices, 2014. www.fao.org/prods/GAP/index en.htm, August 01, 2014.

Gordon, D.C., Hallett, P.D., 2014. An automated microinfiltrometer to measure smallscale soil water infiltration properties. J. Hydrol. Hydromech. 62, 248-252.

Hallett, P.D., Ritz, K., Wheatley, R.E., 2001b. Microbial derived water repellency in golf course soil. International Turfgrass Society Research Journal 9, 518-524.

Hallett, P.D., Young, I.M., 1999. Changes to water repellence of soil aggregates caused by substrate-induced microbial activity. Eur. J. Soil Sci. 50, 35-40.

Hallett, P.D., Baumgartl, T., Young, I.M., 2001. Subcritical water repellency of aggregates from a range of soil management practices. Soil Sci. Soc. Am. J. 65, 184-190.

Harper, R., Mckissock, I., Gilkes, R., Carter, D., Blackwell, D.P., 2000. A multivariate framework for interpreting the effects of soil properties, soil management and landuse on water repellency. J. Hydrol. 231-232, 371-383.

Hermawan, B., Cameron, K.C., 1993. Structural changes in a silt loam under long term conventional or minimum tillage. Soil Till. Res. 26, 139-150.

Igwe, C.A., Akamigbo, F.O.R., Mbagwu, J.S.C., 1999. Chemical and mineralogical properties in soils of southeastern Nigeria in relation to aggregate stability. Geoderma 92 , $111-123$.

Jaramillo, J.D.F., 2003. Efecto de la temperatura de secado del suelo sobre la repelencia al agua en Andisoles bajo cobertura de Pinus patula. Informe de investigación. Universidad Nacional de Colombia, Medellín (36 p).

Jaramillo, J.D.F., 2006. Repelencia al agua en suelos: una síntesis. Revista Acadêmica Colombiana de Ciência, Medellın 30 (115), 215-232.

Kay, B.D., 1990. Rates of change of soil structure under different cropping systems. Adv. 
Soil Sci. 12, 1-52.

King, P.M., 1981. Comparison of methods for measuring severity of water repellence of sandy soils and assessment of some factors that affects its measurement. Aus. J. Soil Res. 19, 275-285.

Kirkegaard, J.A., Hunt, J.R., 2010. Increasing productivity by matching farming system management and genotype in water-limited environments. J. Exp. Bot. 61, 4129-4143.

Kraemer Behrends, F., Fernández, P.L., Castiglioni, M.G., Morrás, H., 2012. Evaluación del tiempo de inmersión de los agregados en el tratamiento de humedecimiento rápido de la técnica de Le Bissonnais. In: Actas del XIX Congreso Latinoamericano de la Ciencia del suelo. AACS. Mar del Plata, Argentina.

Kraemer, F.B., 2015. Influencia de la granulometría y la mineralogía en el comportamiento hidro-físico y estructural en suelos con distinta intensidad y secuencia de cultivos bajo siembra directa. PhD Thesis. Escuela para Graduados Alberto Soriano Facultad de Agronomía, Universidad de Buenos Aires, Argentina.

Le Bissonnais, Y., 1996. Aggregate stability and assessment of soil crustability and erodibility: I. Theory and methodology. Eur. J. Soil Sci. 47, 425-437.

Le Bissonnais, Y., Le Souder, C., 1995. Mesurer la stabilité structurale des sols pour évaluer leur sensibilité à la battance et à l'érosion. Etudes et Gestion des Sols 2 (1), 43-56.

Letey, J., 1969. Measurement of contact angle, water drop penetration time, and critical surface tension. In: DeBano, L.F., Letey, J. (Eds.), Water Repellent Soils. Proc. Symp. University of California, Riverside, pp. 43-47.

Lichner, L., Dlapa, P., Doerr, S.H., Mataix-Solera, J., 2006. Evaluation of different clay mineralogies as additives for soil water repellency alleviation. Appl. Clay Sci. 31, $238-248$.

Mahboubi, A.A., Lal, R., Faussey, N.R., 1993. Twenty-eight years of tillage effects on two soil in Ohio. Soil Sci. Soc. Am. J. 57, 506-512.

Mataix-Solera, J., Doerr, S.H., 2004. Hydrophobicity and aggregate stability in calcareous topsoils from fire-affected pine forest in southeastern Spain. Soil Till. Res. Amsterdam 118 (2), 77-88.

Mataix-Solera, J., Cerdà, A., Arcenegui, V., Jordán, A., Zavala, L.M., 2011. Fire effects on soil aggregation: a review. Earth Sci. Rev. 109, 44-60.

McKissock, I., Gilkes, R.J., Walker, E.L., 2002. The reduction of water repellency by added clay as influenced by clay and soil properties. Appl. Clay Sci. 20, 225-241.

Monnier, G., Stengel, P., Fies, J.C., 1973. Une méthode de mesure de la densité apparente de petits agglomérats terreux: application a l'analyse des systèmes de porosité du sol. Ann. Agron. 24, 533-545.

Morrás, H., Bonel, B., Michelena, R., 2004. Características microestructurales del horizonte superficial de algunos suelos pampeanos bajo siembra directa. In: Actas XIX Congreso Argentino de la Ciencia del Suelo, Paraná, (Editado en CD).

Morrás, H., Bonel, B., Fernandez, P., Kraemer, F., Alvarez, C., 2012. Topsoil microstructural models in no-till Pampean Mollisols of Argentina. Morphology and development. In: Proceedings of the 14th International Working Meeting on Soil Micromorphology. Lleida, España.

Novelli, L.E., Caviglia, O.P., Melchiori, R.J.M., 2011. Impact of soybean cropping frequency on soil carbon storage in Mollisols and Vertisols. Geoderma 167-168, 254-260.

Novelli, L.E., Caviglia, O.P., Wilson, M.G., Sasal, M.C., 2013. Land use intensity and cropping sequence effects on aggregate stability and C storage in a vertisol and a Mollisol. Geoderma 195-196, 260-267.

Perfect, E., Kay, B.D., van Loon, W.K.P., Sheard, R.W., Pojasok, T., 1990. Factors influencing soil structural stability within a growing season. Soil Sci. Soc. Am. J. 54, 173-179.

Puget, P., Angers, D.A., Chenu, C., 1999. Nature of carbohydrates associated with waterstable aggregates of two cultivated soils. Soil Biol. Bio. 31, 55-63.

Reid, J.B., Goss, M.J., 1982. Interactions between soil drying due to plant water use and decreases in aggregate stability caused by maize roots. Soil Sci. 33, 47-53.

Ritsema, C.J., Dekker, L.W., Hendrick, J.M.H., Hamminga, W., 1993. Preferential flow mechanism in a water repellent sandy soil. Water Res. Res. 29, 2183-2193.

Ritsema, C.J., Dekker, L.W., van den Elsen, E.G.M., Oostindie, K., Nieber, J.L., 1997. Recurring fingered flow pathways in a water repellent sandy field soil. Hydrol. and Earth Sys. Sci. (4), 777-786.

Rosa, S.M., Kraemer, F.B., Soria, M.A., Guerrero, L.D., Morrás, H.J.M., Figuerola, E.L.M., Erijman, L., 2014. The influence of soil properties on denitrifying bacterial communities and denitrification potential in no-till production farms under contrasting management in the Argentinean Pampas. Appl. Soil Ecol. 75, 172-180.

Rougier, M., 1981. Secretory activity at the root cap. In: Tanner, W., Loews, F.A. (Eds.), Encyclopedia of Plant Physiology, New Series. Plant Carbohydrates II Vol 13B. Springer Verlag, Berlin, pp. 542-574.
Sanzano, G.A., Corbella, R.D., García, J.R., Fadda, G.S., 2005. Degradación física y química de un Haplustol típico bajo distintos sistemas de manejo de suelo. Ci. Suelo (Argentina) 23, 93-100.

Sasal, C., Andriulo, A., Taboada, M., 2006. Soil Porosity characteristics and water movement under zero tillage in silty soils in argentinian pampas. Soil Till. Res. 87, 9-18.

Sasal, C., 2012. Factores condicionantes de la evolución estructural de suelos limosos bajo siembra directa. Efecto sobre el balance de agua. Tesis Doctoral. Área Ciencias Agropecuarias. Escuela para Graduados. FAUBA, 144.

Sasal, C., Castiglioni, M.G., Ferreiro, J.P., Wilson, M.G., Oszust, J., 2009. Propiedades hidrológicas edáficas bajo diferentes secuencias de cultivos en siembra directa. In: Silva, O. (Ed.), Estudios en la Zona no Saturada del Suelo. vol IX (Barcelona).

Sasal, M.C., Castiglioni, M.G., Wilson, M.G., 2010. Effect of crop sequences on soil properties and runoff on natural rainfall erosion plots under no tillage. Soil Till. Res. 108, 24-29.

Scott, D.F., 2000. Soil wettability in forested catchments in South Africa; as measured by different methods and as affected by vegetation cover and soil characteristics. J. Hydrol. 231-232, 87-104.

Simon, T., Javurek, M., Mikanova, O., Vach, M., 2009. The influence of tillage systems on soil organic matter and soil hydrophobicity. Soil Till. Res. 105, 44-48.

Six, J., Bossuyt, H., Degryze, S., Denef, K., 2004. A history of research on the link between (micro) aggregates, soil biota, and soil organic matter dynamics. Soil Till. Res. 79 $7-31$.

SMN, 2012. Servicio Meterológico Nacional, http://www.smn.gov.ar, (accessed 01 October 2018).

Studdert, G.A., Domínguez, G.F.Agostini, 2010. Cropping systems to manage southeastern pampas' Mollisol health. I. Organic C and mineralizable N. In: Liu, X, Song, C, Cruse, RM, Huffman, T (Eds.), New Advances in Research and Management of World Mollisols. Proceedings «International Symposium on Soil Quality and Management of World Mollisols. Harbin, Heilongjiang, R.P. China, pp. 199-200 July 2010.

Täumer, K., Stoffregen, H., Wessolek, G., 2005. Determination of repellency distribution using soil organic matter and water content. Geoderma 125, 107-115.

Tillman, R.W., Scotter, D.R., Wallis, M.G., Clothie, B.E., 1989. Water-repellency and its measurement by using intrinsic sorptivity. Aust. J. Soil Res. 27, 637-644.

Urbanek, E., Hallett, P., Feeney, D., Horn, D., 2007. Water repellency and distribution of hydrophilic and hydrophobic compounds in soil aggregates from different tillage systems. Geoderma 140, 147-155.

Varela, M.F., Fernández, P.L., Alvarez, C., Scianca, C., Rubio, G., 2010. Propiedades físicas que varían por la incorporación de cultivos de cobertura en Hapludoles franco arenosos. XXII Congreso Argentino de la Ciencia del Suelo, Rosario.

Viglizzo, E.F., Frank, F.C., Carreno, L.V., Jobbágy, E.G., Pereyra, H., Clatt, J., Pincén, D., Ricard, M.F., 2011. Ecological and environmental footprint of 50 years of agricultural expansion in Argentina. Global Change Biol 17, 959-973.

Vogelmann, E.S., Reichert, J.M., Reinert, D.J., Mentges, M.I., Vieira, D.A., Peixoto de Barros, C.A., Fasinmirin, J.T., 2010. Water repellency in soils of humid subtropical climate of Rio Grande do Sul, Brazil. Soil Till. Res. 110, 126-133.

Vogelmann, E.S., Reichert, J.M., Reinert, D.J., Mentges, M.I., Vieira, D.A., de Barros, C.A.P., Fasinmirin, J.T., 2010. Water repellency in soils of humid subtropical climate of Rio Grande do Sul, Brazil. Soil Till. Res. 110 (1), 126-133.

Vogelmann, E.S., Reichert, J.M., Prevedello, J., Awe, G.O., Mataix-Solera, J., 2013. Can occurrence of soil hydrophobicity promote the increase of aggregates stability? Catena 110, 24-31.

Wall, L.G., 2011. The BIOSPAS consortium: soil biology and agricultural production. In: de Bruijn, F.J. (Ed.), Handbook of Molecular Microbial Ecology I. John Wiley \& Sons, Inc, Hoboken, NJ, USA, pp. 299-306.

Wallis, M.G., Horne, D.J., 1992. Soil water repellency. Adv. Soil Sci. 20, 91-146.

Wander, M.M., 2004. Soil organic matter fractions and their relevance to soil function. En Magdoff, F., Weil, R.: Advances in Agroecology. CRC, Boca Raton, FL, USA, pp. 67-102.

Ward, P.R., Oades, J.M., 1993. Effect of clay mineralogy and exchangeable cations on water-repellency in clay-amended sandy soils. Aust. J. Soil Res. 31, 351-364.

White, N.A., Hallett, P.D., Feeney, D., Palfreyman, J.W., Ritz, K., 2000. Changes to water repellence of soil caused by the growth of white-rot fungi: studies using a novel microcosm system. FEMS Microbiol. Lett. 184, 73-77.

Wischmeier, W.H., Johnson, C.B., Cross, B.V., 1971. A soil erodibility nomograph for farmland and construction sites. J. Soil Water Conserv. 26, 189-193.

Zaher, H., Caron, J., Ouaki, B., 2005. Modeling aggregate internal pressure evolution following immersion to quantify mechanisms of stability. Soil Sci. Soc. Am. J. 69 (1), 12. 